\title{
Oxidized LDL Activates Fas-mediated Endothelial Cell Apoptosis
}

\author{
Masataka Sata* and Kenneth Walsh ${ }^{\star \ddagger}$ \\ *Division of Cardiovascular Research, St. Elizabeth's Medical Center, Tufts University School of Medicine, Boston, Massachusetts 02135; \\ ${ }^{\ddagger}$ Program in Cell, Molecular, and Developmental Biology, Sackler School of Biomedical Sciences, Tufts University, Boston, \\ Massachusetts 02111
}

\begin{abstract}
Oxidized low density lipoproteins (OxLDL) promote chronic inflammatory responses in the vasculature that give rise to atherosclerotic plaques. Fas ligand (FasL) is naturally expressed on the vascular endothelium where it can induce apoptosis in Fas-expressing immune cells as they enter the vessel wall. Although vascular endothelial cells are normally resistant to Fas-mediated cell death, OxLDL were shown to induce apoptosis in cultured endothelial cells and endothelium of arterial explants by a process that could be inhibited with Fas L neutralizing antibodies. OxLDL-induced cell death was also reduced in the aortic endothelium cultured from gld (FasL-I-) and lpr (Fas-I-) mice as compared with wild-type mice. OxLDL acted by sensitizing endothelial cells to death signals from the Fas receptor. Thus, the ability of OxLDL to promote Fas-mediated endothelial cell suicide may be a feature that contributes to their atherogenicity. (J. Clin. Invest. 1998. 102:1682-1689.) Key words: endothelium • oxidized LDL • apoptosis • Fas • Fas ligand
\end{abstract}

\section{Introduction}

It is firmly established that elevated plasma concentrations of LDL are associated with accelerated atherogenesis, and clinical trials demonstrate that LDL-lowering treatments reduce the risk of death in patients with coronary artery disease (1). Recent evidence suggests that oxidative modification of LDL renders it more atherogenic (2) and oxidized LDL (OxLDL) ${ }^{1}$ has been identified in atherosclerotic lesions $(3,4)$. OxLDL and its lipid constituents have numerous detrimental effects on endothelial cell function (5-7) including the induction of apoptosis (8-11).

Fas is a type I membrane protein that initiates an apoptotic signal when bound to its ligand, FasL (12). Fas is widely ex-

Address correspondence to Dr. Kenneth Walsh, Division of Cardiovascular Research, St. Elizabeth's Medical Center, 736 Cambridge Street, Boston, MA 02135. Phone: 617-562-7501; FAX: 617-562-7506; E-mail:kwalsh@opal.tufts.edu

Received for publication 25 March 1998 and accepted in revised form 8 September 1998.

1. Abbreviations used in this paper: FasL, Fas ligand; HAECs, human aortic endothelial cells; HUVECs, human umbilical vein endothelial cells; LPC, L- $\alpha$-palmitoyl lysophosphatidylcholine; MM-LDL, minimally modified LDL; OxLDL, oxidized low density lipoproteins; TUNEL, TdT-mediated dUTP nick-end labeling.

J. Clin. Invest.

(C) The American Society for Clinical Investigation, Inc. 0021-9738/98/11/1682/08 \$2.00

Volume 102, Number 9, November 1998, 1682-1689

http://www.jci.org pressed, but few cell types express FasL. FasL is expressed by immune-privileged tissues of eye and testis $(13,14)$, as well as by some tumors, where it may contribute to their ability to evade immune detection (15-17). FasL is also expressed on vascular endothelial cells, where it appears to have an antiinflammatory function (18). Under normal conditions, endothelial cells are resistant to Fas-mediated apoptosis, although they express detectable Fas on their cell surface (18). In contrast, Fas ligand can readily induce apoptosis in Fas-bearing vascular smooth muscle cells (19). Because recent evidence suggests that atherosclerosis is initiated by an aberrant immune response triggered by elevated lipid levels (20-22), we investigated whether oxidized lipid-induced endothelial cell apoptosis is mediated by the Fas cell death pathway. Here, we show that OxLDL induces endothelial apoptosis through FasFasL interaction, and that endothelial cells are markedly sensitized to Fas-mediated apoptosis by OxLDL. The results may provide insights about the pathogenesis of the accelerated atherosclerosis in patients with hyperlipidemia.

\section{Methods}

Cells and reagents. Human aortic endothelial cells (HAECs) were obtained from Clonetics (San Diego, CA). Human umbilical vein endothelial cells (HUVECs) were isolated as described (18). Both HAECs and HUVECs were cultured in EGM medium (Clonetics) containing $2 \% \mathrm{FBS}, 10 \mathrm{ng} / \mathrm{ml}$ human EGF, $1.0 \mu \mathrm{g} / \mathrm{ml}$ hydrocortisone, and $12 \mu \mathrm{g} / \mathrm{ml}$ bovine brain extract. LDL was isolated by sequential ultracentrifugation $(d=1.019-1.063)$ from freshly drawn, citrated normolipidemic human plasma to which EDTA was added. LDL was oxidized in the presence of $5 \mu \mathrm{M} \mathrm{CuSO}_{4}$ for $24 \mathrm{~h}$ at $25^{\circ} \mathrm{C}$, and the degree of oxidation was assessed by the increase of mobility on $1 \%$ agarose gel (1.3-1.5 versus native LDL). Different preparations of OxLDL displayed similar electrophoretic mobilities. For comparison, commercially available preparations of native and copper-oxidized LDLs (Sigma Chemical Co., St. Louis, MO, and Biomedical Technologies, Inc., Stoughton, MA, respectively) were used in selected experiments. The formation of thiobarbituric acid-reactive substances was 17.8 nanomoles of malondialdehyde/mg protein using an OxLDL preparation with relative electrophoretic mobility of 1.4. Minimally modified LDL (MM-LDL) was prepared by dialyzing native LDL against $9 \mu \mathrm{M} \mathrm{FeSO}_{4}$ in PBS for $72 \mathrm{~h}$ at $4^{\circ} \mathrm{C}$ as described (23). The electrophoretic mobility increased 1.1-1.2 versus native LDL. Acetylation of LDL was performed with excess acetic anhydride. Endotoxin contamination in OxLDL was measured with the coagulation Limulus amebocyte lysate assay using a commercially available kit (E-TOXATE, Sigma Chemical Co.).

Detection of Fas and FasL expression on endothelial cells. $90 \%$ confluent HAECs and HUVECs were incubated with OxLDL $(150 \mu \mathrm{g}$ protein $/ \mathrm{ml}$ ) or L- $\alpha$-palmitoyl lysophosphatidylcholine (LPC, $45 \mu \mathrm{M}$, Sigma Chemical Co.) at $37^{\circ} \mathrm{C}, 5 \% \mathrm{CO}_{2}$ for $13 \mathrm{~h}$, and detached from the culture plate with $0.5 \%$ EDTA. To determine FasL expression, endothelial cells were incubated with an anti-FasL antibody (C-20, Santa Cruz Biotechnology, Santa Cruz, CA) or with rabbit IgG followed by a FITC-conjugated antibody against rabbit Ig (Biosource, Camarillo, CA). To determine Fas expression, endothelial cells were incubated with an FITC-conjugated anti-Fas monoclonal antibody 
(clone UB2, Immunotech, Westbrook, ME) or an FITC-conjugated mouse IgG. Immunofluorescence staining was analyzed by FACS (fluorescence-activated cell sorter) (Becton Dickinson, Mountain View, CA).

Detection of DNA fragmentation by agarose gel electrophoresis. HUVECs $\left(10^{6}\right)$ were incubated in the presence or absence of native LDL (300 $\mu \mathrm{g}$ protein/ml), OxLDL (300 $\mu \mathrm{g}$ protein/ml), LPS (100 endotoxin $\mathrm{U} / \mathrm{ml})$, or a neutralizing anti-FasL antibody $(24)(10 \mu \mathrm{g} / \mathrm{ml}$, 4H9, MBL, Nagoya, Japan) for $36 \mathrm{~h}$. Attached cells and floating cells were combined and lysed in $0.33 \mathrm{ml}$ of lysis buffer $(10 \mathrm{mM}$ Tris- $\mathrm{HCl}$, pH 8.0, $1 \mathrm{mM}$ EDTA, $0.2 \%$ Triton X-100) followed by incubation with $0.1 \mathrm{mg} / \mathrm{ml} \mathrm{RNAase} \mathrm{A} \mathrm{for} 1 \mathrm{~h}$ at $37^{\circ} \mathrm{C}$ and $0.2 \mathrm{mg} / \mathrm{ml}$ proteinase $\mathrm{K}$ for $3 \mathrm{~h}$ at $50^{\circ} \mathrm{C}$. Ethanol-precipitated DNA was resuspended in TE buffer, fractionated on $1.5 \%$ agarose gel in $1 \times$ TBE buffer, and stained with ethidium bromide.

Detection of DNA fragmentation by TdT-mediated dUTP nickend labeling (TUNEL). $70 \%$ confluent HUVECs were incubated in the presence or absence of OxLDL (300 $\mu \mathrm{g}$ protein $/ \mathrm{ml})$, a neutralizing anti-FasL antibody (24) $(10 \mu \mathrm{g} / \mathrm{ml}, 4 \mathrm{H} 9)$, or an agonistic anti-Fas antibody $(0.5 \mu \mathrm{g} / \mathrm{ml}, \mathrm{CH} 11, \mathrm{MBL})$ for $16 \mathrm{~h}$ at $37^{\circ} \mathrm{C}, 5 \% \mathrm{CO}_{2}$. Attached cells harvested by trypsinization and floating cells were combined, fixed in $4 \%$ paraformaldehyde, permeabilized in $0.1 \%$ Triton $\mathrm{X}-100,0.1 \%$ sodium citrate, and incubated with TUNEL solution (Boehringer Mannheim, Indianapolis, IN) in the absence or in the presence of terminal deoxynucleotidyl transferase. After washing in PBS, fluorescence intensity was analyzed by FACS.

Cell viability assay. HAECs or HUVECs were cultured in a 96well plate at $80 \%$ confluency and incubated in the presence or absence of OxLDL (300 $\mu \mathrm{g}$ protein $/ \mathrm{ml})$, LPC-C16:0 $(55 \mu \mathrm{M})$, a neutralizing anti-FasL antibody $(10 \mu \mathrm{g} / \mathrm{ml}, 4 \mathrm{H} 9)$, or an agonistic anti-Fas antibody $(0.5 \mu \mathrm{g} / \mathrm{ml}, \mathrm{CH} 11)$ for $18 \mathrm{~h}$. Cell viability was measured by means of MTT (dimethylthiazol-diphenyltetrazolium bromide) assay (24) and percentage of cell death was calculated as $100 \times(1-$ viability of treated endothelial cells/viability of untreated endothelial cells).

Organ culture. Organ culture experiments were performed as described (25). Carotid arteries were excised from male New Zealand white rabbit, cut into 1-2-mm-long ring segments, and washed in PBS. The rings was cultured in M199 medium containing $0.5 \%$ FBS and OxLDL $(100 \mu \mathrm{g}$ protein $/ \mathrm{ml})$ in the absence or presence of the anti-FasL antibodies (4H9 $10 \mu \mathrm{g} / \mathrm{ml}$ and C-20 $10 \mu \mathrm{g} / \mathrm{ml})(24,26)$ for
$24 \mathrm{~h}$, or $64 \mathrm{~h}$ at $37^{\circ} \mathrm{C}, 5 \% \mathrm{CO}_{2}$. The rings were washed in PBS and snap-frozen in OCT compound (Miles, Elkhart, IN). Cryosections (5 $\mu \mathrm{M})$ from the rings harvested at $64 \mathrm{~h}$ were stained for endothelial cells using an anti-CD31 monoclonal antibody (clone JC/70A, DAKO) as described (18). Cryosections from the rings harvested at $24 \mathrm{~h}$ was stained by TUNEL technique as described (18). Nuclei were counterstained with propidium iodide (Boehringer Mannheim) and mounted for fluorescence (Kirkegaard \& Perry Laboratories, Gaithersburg, $\mathrm{MD})$. Specimens were examined and photographed on a laser confocal microscope (ODYSSEY CLSM, Noran, Middleton, WI).

Aortic rings from male C57BL/6J mice, B6Smn-gld ${ }^{\mathrm{Fas}-/-}$ mice, and B6-MRL-lpr ${ }^{\text {Fas }-/-}$ mice (Jackson Laboratories, Bar Harbor, ME) were incubated with OxLDL $(150 \mu \mathrm{g}$ protein $/ \mathrm{ml})$ in M199 medium containing $0.5 \%$ FBS for $72 \mathrm{~h}$, fixed with $4 \%$ paraformaldehyde, and embedded in paraffin. Sections $(6 \mu \mathrm{M})$ were stained for CD31 (clone MEC 13.3, PharMingen, San Diego, CA). The proportion of luminal surface containing endothelium was measured by quantitative morphometric analysis using a computerized sketching program and expressed as mean \pm SEM.

\section{Results}

To examine cell surface Fas and FasL, FACS analysis was performed on HUVECs treated with OxLDL or L- $\alpha$-palmitoyl lysophosphatidylcholine (LPC-C16:0), a component of OxLDL. Incubation with OxLDL $(150 \mu \mathrm{g}$ protein/ml) or LPC-C16:0 (45 $\mu \mathrm{M})$ upregulated FasL expression on HUVECs (Fig. 1). In contrast, treatment with OxLDL or LPC did not detectably alter HUVEC cell surface Fas expression. Treatment of HAECs with OxLDL or LPC also led to an increase in cell surface FasL expression, whereas Fas expression remained unchanged (M. Sata and K. Walsh, unpublished data). Higher doses of oxidized lipid, that more effectively induce cytotoxicity, also upregulated FasL expression as determined by Western immunoblotting (M. Sata and K. Walsh, unpublished data).

HAECs treated with OxLDL displayed characteristics of apoptosis including cell shrinkage and nuclear condensation (Fig. 2 A). The expression of the apoptotic phenotype was
Fas expression
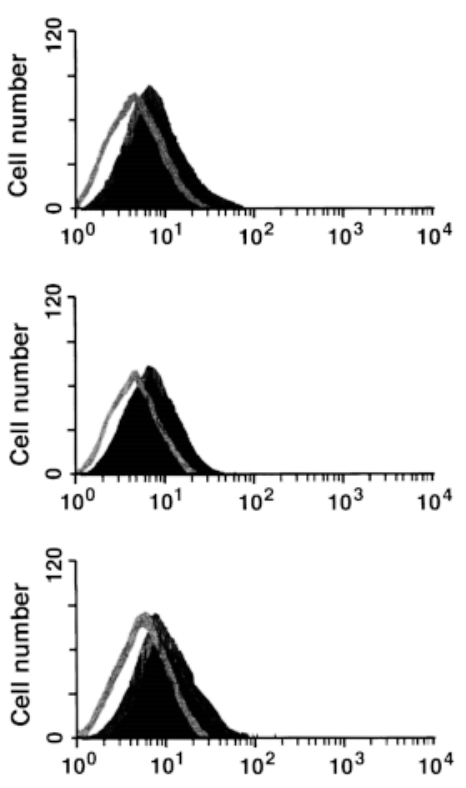

Fluorescence intensity
FasL expression
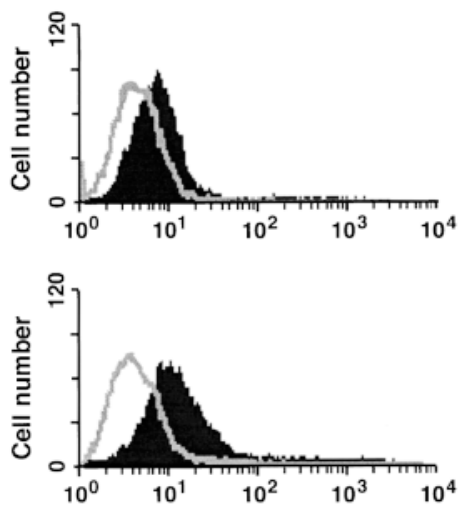

Figure 1. OxLDL upregulates the FasL expression on human endothelial cells. $90 \%$ confluent HUVECs were incubated with $150 \mu \mathrm{g}$ protein/ml of OxLDL or $45 \mu \mathrm{M}$ of LPC for $13 \mathrm{~h}$ and detached from the culture plate with $0.5 \%$ EDTA. To determine FasL expression, endothelial cells were incubated with an anti-FasL antibody (C-20, Santa Cruz Biotechnology) (filled curve) or with rabbit IgG (open curve) followed by an FITC-conjugated antibody against rabbit Ig. To detect Fas expression, HUVECs were incubated with an FITC-conjugated anti-Fas monoclonal antibody (clone UB2; Immunotech, Westbrook, ME) (filled curve) or an FITC-conjugated mouse IgG (open curve). Immunofluorescence staining was analyzed by FACS. 
A
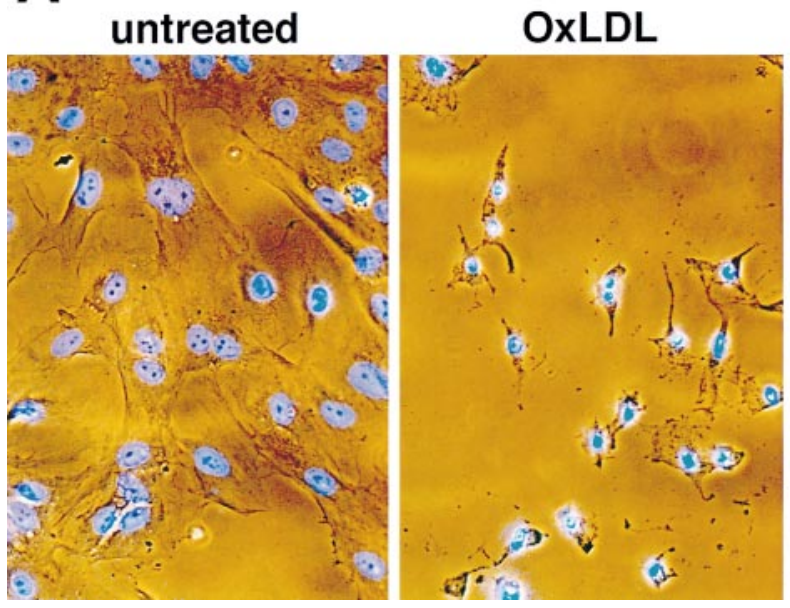

\section{OxLDL $+\alpha$ FasL}

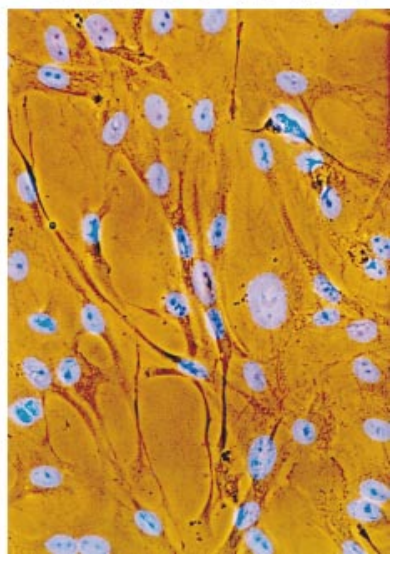

B

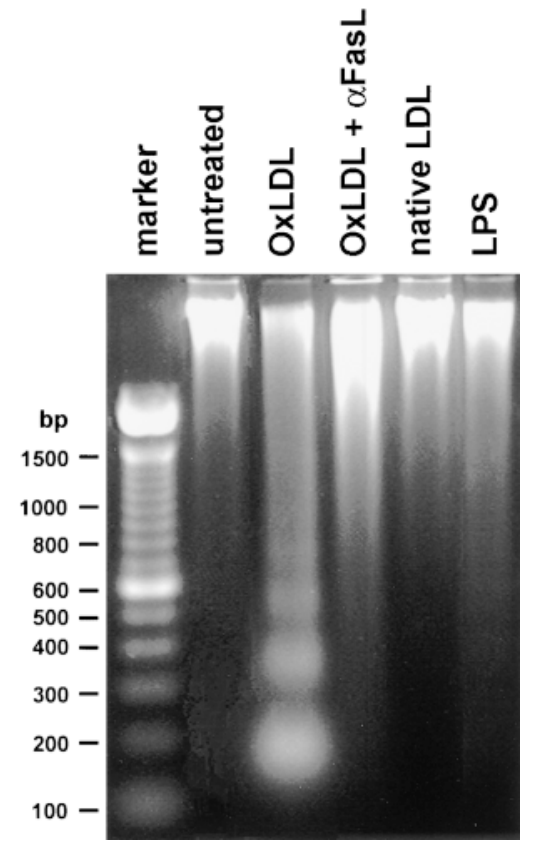

C

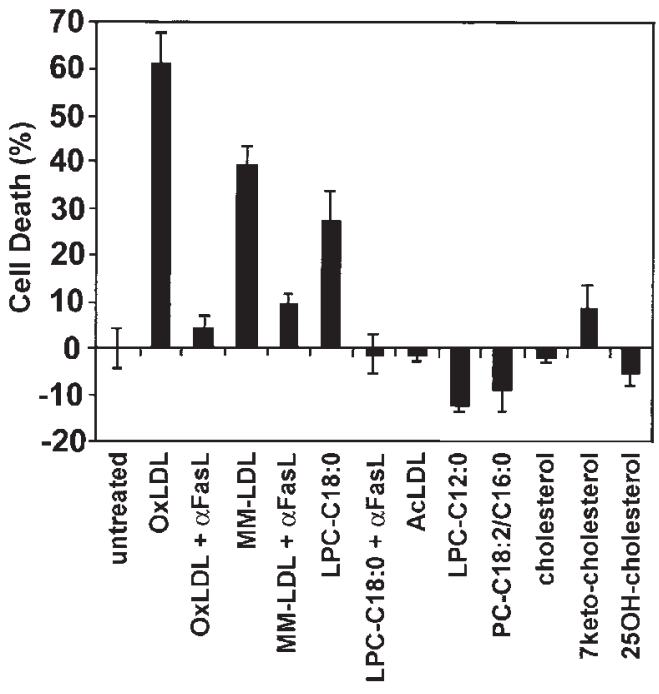

Figure 2. OxLDL-induced endothelial cell apoptosis is blocked by a neutralizing anti-FasL antibody. $(A)$ The apoptotic phenotype is induced by OxLDL. HAECs were incubated with OxLDL ( $300 \mu \mathrm{g}$ protein $/ \mathrm{ml})$ in the absence (middle) and presence (right) of a neutralizing anti-FasL antibody ( $\alpha$ FasL, $10 \mu \mathrm{g} / \mathrm{ml}, 4 \mathrm{H} 9$, MBL, Nagoya, Japan). After $22 \mathrm{~h}$, cells were fixed in $4 \%$ paraformaldehyde, stained with Hoechst 33258, and observed under the microscope equipped with phase-contrast and epifluorescence optics. ( $B$ ) DNA fragmentation is induced by OxLDL. HUVECs $\left(10^{6}\right)$ were incubated in the presence or absence of native LDL $(300 \mu \mathrm{g}$ protein $/ \mathrm{ml}$ ), OxLDL (300 $\mu \mathrm{g}$ protein/ml), lypopolysaccharide from E. coli 0.55 (LPS, 100 endotoxin U/ml; Sigma Chemical Co.), or a neutralizing anti-FasL ( $\alpha$ FasL, 4 H9) for $36 \mathrm{~h}$. The genomic DNA was isolated and fractionated on $1.5 \%$ agarose gel in $1 \times$ TBE buffer, and stained with ethidium bromide. $(C)$ Decreased cell viability is induced by OxLDL and other lipid components. HUVECs were incubated with OxLDL, minimally modified LDL $(M M-L D L)(300 \mu \mathrm{g}$ protein/ml), L- $\alpha$-lysophosphatidylcholine, stearoyl (LPC-C18:0) $(45 \mu \mathrm{M})$, acetylated LDL $(A c L D L)(300 \mu \mathrm{g}$ protein/ml), L- $\alpha$-lysophosphatidylcholine, lauroyl (LPC-C12:0) $(100 \mu \mathrm{M}), \beta$-lynoleoyl- $\gamma$-palmitoyl (PC-C18:2,16:0), cholesterol $(200 \mu \mathrm{M})$, 7-ketocholesterol (200 $\mu \mathrm{M})$, or 25-hydroxycholesterol $(25 \mathrm{OH}$-cholesterol $)(200 \mu \mathrm{M})$ in the absence or presence of the neutralizing anti-FasL antibody $(\alpha \mathrm{FasL}, 4 \mathrm{H} 9)(10 \mu \mathrm{g} / \mathrm{ml})$ for $24 \mathrm{~h}$. Cell viability was determined by means of MTT assay (14) and \% cell death was calculated as $100 \times(1-$ viability of treated endothelial cells/viability of untreated endothelial cells). Data are presented as mean \pm SEM. markedly attenuated when cultures were coincubated with 4H9 anti-FasL antibody that neutralizes the cytotoxicity of FasL (24). Interestingly, OxLDL-treated endothelial cells protected from death by anti-FasL antibody still attained a distinctive elongated cell morphology (27) (Fig. $2 A$ ), indicating that other actions of OxLDL are not blocked by the neutralizing anti-FasL antibody. Similar observations were also made with HUVECs treated with $4 \mathrm{H} 9$ and HAECs treated with C-20 anti-FasL antibody that also has a neutralizing activity (26) (M. Sata and K. Walsh, unpublished data). In the presence of neutralizing anti-FasL antibody, HUVEC apoptosis could be induced with $10 \mu \mathrm{M}$ staurosporine, indicating that other apoptosis-inducing signals were not inhibited by the antibody (data not shown).

Eight preparations of OxLDL were tested and all produced similar extents of apoptosis in HAECs and HUVECs. Though preparations varied in their dose-response characteristics, cell death typically occurred at concentration of OxLDL above $250 \mu \mathrm{g} / \mathrm{ml}$ in medium containing $2 \%$ FBS. In comparison, others have reported that $16 \%$ apoptosis when HUVECs were treated with $25 \mu \mathrm{g}$ protein/ml OxLDL for $48 \mathrm{~h}$ in serum-free medium (11) or $54 \%$ apoptosis when the endothelial cell line CRL-1998 was treated with $200 \mu \mathrm{g}$ protein/ml OxLDL for $24 \mathrm{~h}$ in serum-free medium (8). In our studies, neutralizing antiFasL antibody was most effective in inhibiting apoptosis at OxLDL concentrations below $400 \mu \mathrm{g} / \mathrm{ml}$, and less effective at higher OxLDL concentrations.

Genomic DNA prepared from OxLDL-treated HUVECs showed a DNA ladder upon electrophoresis, a well established marker of apoptosis (Fig. 2 B). OxLDL-induced DNA frag- 
mentation was markedly attenuated by coincubation with neutralizing anti-FasL antibody. Native LDL did not induce DNA fragmentation in HUVECs, nor did endotoxin, a common contaminant of lipoprotein preparations, when incubated at greater than a 300-fold excess of the levels detected in the OxLDL preparation (M. Sata and K. Walsh, unpublished data).

HUVECs treated with OxLDL also showed decreased mitochondrial function in the MTT assay (Fig. $2 C$ ), another indicator of apoptotic cell death (24). Consistent with the data presented above, incubation with neutralizing anti-FasL antibody inhibited the decrease in cell viability that was induced by incubation with OxLDL. LPC-C18:0, a component of OxLDL, also induced endothelial cell death as assessed by decreased mitochondrial function (Fig. $2 C$ ). Neutralizing anti-FasL antibody inhibited apoptosis induced by $45 \mu \mathrm{M}$ LPC-C18:0. At higher LPC-C18:0 concentrations $(>60 \mu \mathrm{M})$ the neutralizing antibody was ineffective (M. Sata and K. Walsh, unpublished data). MM-LDL also promoted endothelial cell apoptosis and coincubation with the neutralizing anti-FasL antibody reduced cell death induced by this agent (Fig. $2 C$ ). Unlike OxLDL that is recognized by the endothelium cell scavenger receptor $(28$, 29), MM-LDL is recognized by the LDL receptor, yet it still promotes atherogenesis by acting as an inflammatory agent $(23,30)$. Acetylated LDL, which is internalized by endothelial cells but lacks biological effects $(31,32)$, did not affect endothelial cell viability. LPC-C12:0, which does not inhibit endothelial cell migration (6), also did not affect endothelial cell viability. Cholesterol and oxysterols (7-ketocholesterol and 25-hydroxycholesterol), as well as the phosphatidylcholine PC-C18:2/16:0, did not kill endothelial cells.

Arterial organ culture was used to study endothelial cell viability in a system with intact morphology and minimal cell division (25). Apoptotic endothelial cell death was detected in rings prepared from rabbit carotid artery that were incubated with OxLDL (100 $\mu \mathrm{g}$ protein $/ \mathrm{ml}$ in $0.5 \% \mathrm{FBS})$ for $24 \mathrm{~h}$ as assessed by fluorescent detection of TUNEL-positive DNA (Fig.
A

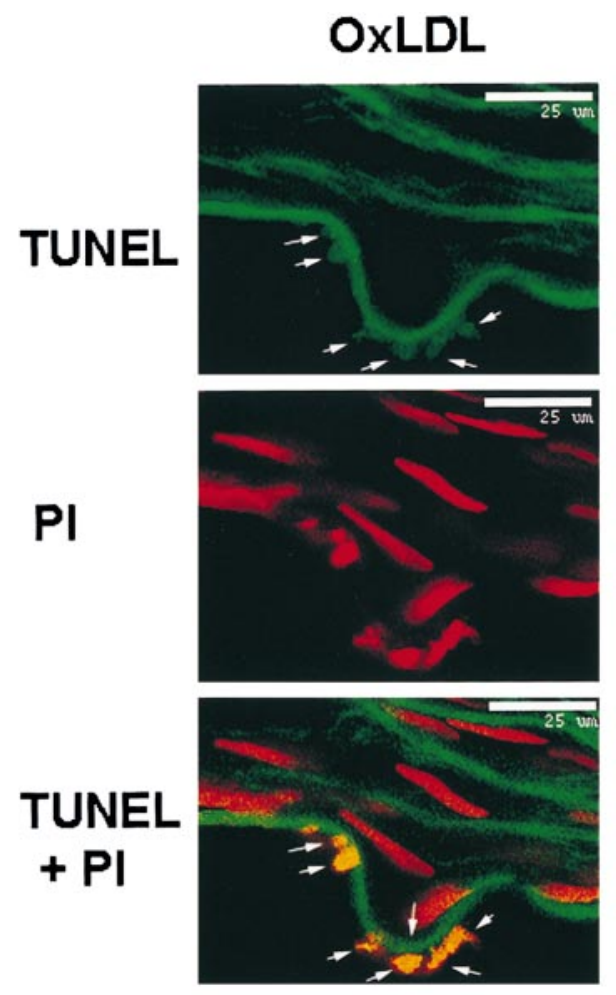

B
Medium

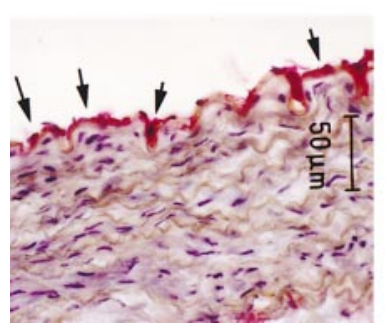

\section{OxLDL $+\alpha$ FasL}
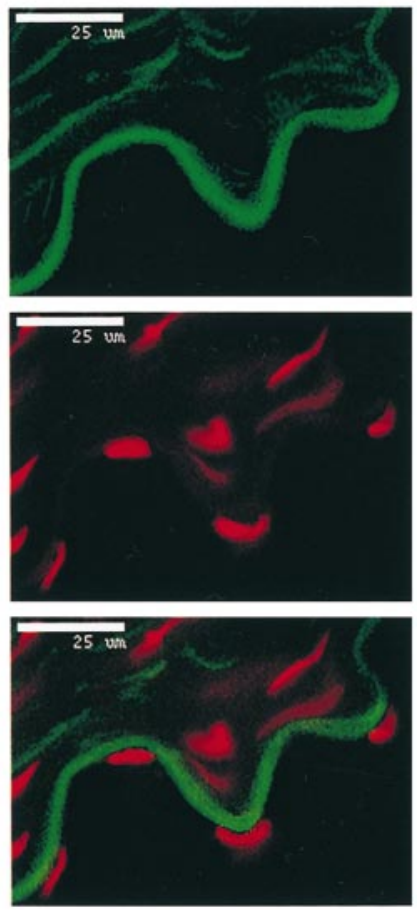

Figure 3. OxLDL induces endothelial cell apoptosis through Fas-FasL interaction in an organ culture of rabbit carotid artery. Rings from rabbit carotid arteries were treated with OxLDL in the absence or presence of the neutralizing anti-FasL antibodies ( $\alpha$ FasL, $4 \mathrm{H} 9,10 \mu \mathrm{g} / \mathrm{ml}$, and C-20, $10 \mu \mathrm{g} / \mathrm{ml}$ ), and harvested at $24 \mathrm{~h}$ and $64 \mathrm{~h}$. $(A)$ Rings harvested at $24 \mathrm{~h}$ were stained with TUNEL (green) to detect fragmented chromatin and propidium iodide $(r e d)$ to detect total chromatin and examined by laser confocal microscopy. Apoptotic nuclei are shown as yellow with a filter for rhodamine and fluorescein. The internal elastic lamina containing autofluorescent elastin is visible with a filter specific for fluorescein. Bar, $25 \mu \mathrm{M}$. (B) Arteries harvested at $64 \mathrm{~h}$ were stained for CD31 (clone JC/70A, DAKO), an endothelial cell marker, using FastRed chromagen (Biogenex, San Ramon, CA). Endothelium is indicated by arrows. Bar, $50 \mu \mathrm{M}$. 


\section{wild}
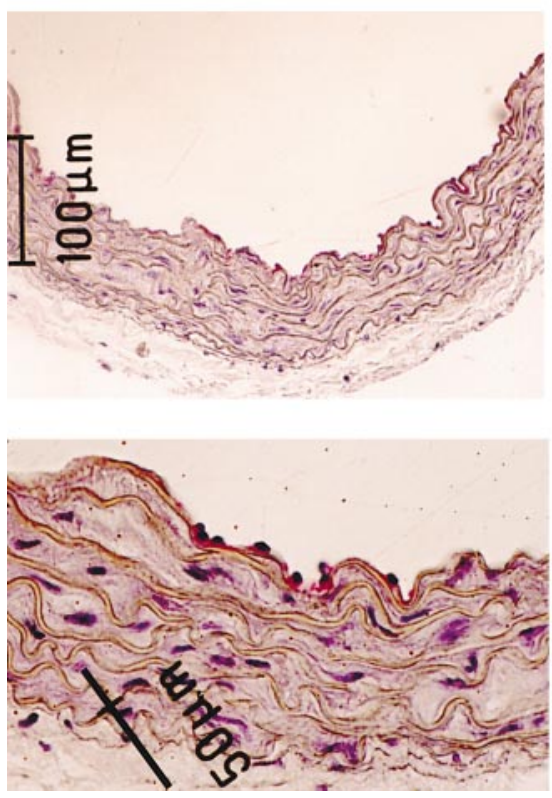

gld (FasL -/-)
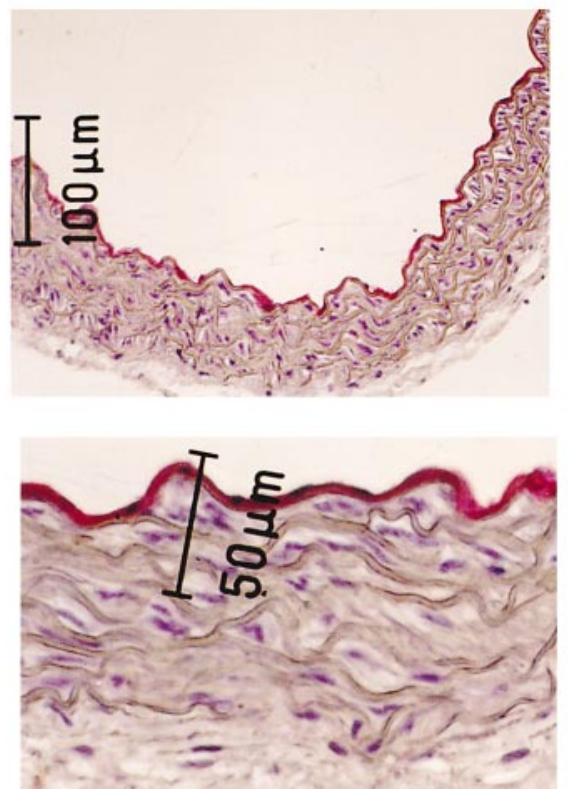

Ipr (Fas -l-)
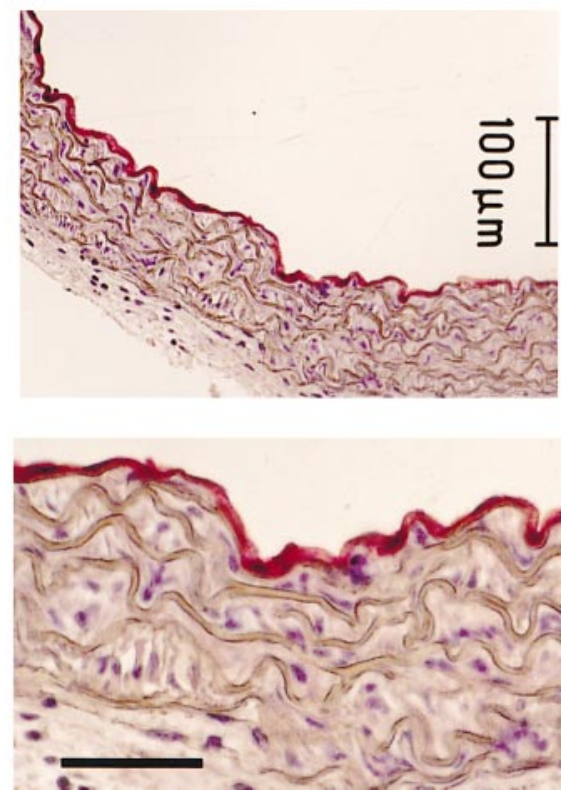

Figure 4. Endothelial cells from $g l d$ or $l p r$ mice are resistant to OxLDL-induced apoptosis. Aortic rings from male C57BL/6J mice, B6Smn$g l d^{\text {FasL-1- }}$ mice, and B6-MRL-lpr $r^{\text {Fas-l- }}$ mice were incubated with OxLDL $(150 \mu \mathrm{g}$ protein $/ \mathrm{ml})$ for $72 \mathrm{~h}$. Sections were stained for CD31 (clone MEC 13.3, PharMingen) with FastRed chromagen, counterstained with Mayer's hematoxylin, and observed in lower (top) or higher magnification (bottom).

$3 A$ ). Treatment with OxLDL also led to notable losses of endothelium by $64 \mathrm{~h}$ (Fig. $3 \mathrm{~B}$ ). Consistent with observations with cultured cells, apoptosis and loss of endothelium was inhibited by coincubating the OxLDL with neutralizing antiFasL antibodies. OxLDL did not induce apoptosis in medial smooth muscle cells under the conditions of these assays.

OxLDL-induced endothelial cell disruption was also examined in cultured aortic rings from gld or lpr mice that lack functional FasL or Fas, respectively ( $n=5$ for each group). Endothelium from C57BL/6J wild-type mice was largely destroyed after a 3-d incubation with OxLDL (Fig. 4). However, aortic endothelia of gld or $l p r$ mice were relatively resistant to OxLDL-induced cell death. $49.7 \pm 6.6 \%$ of the endothelium was disrupted in aortic rings from wild-type mice after treatment with $150 \mu \mathrm{g} /$ protein OxLDL, but only $10.4 \pm 1.1 \%$ or $9.9 \pm 1.7 \%$ of the luminal surface lost endothelium in rings from gld or $l p r$ mice, respectively $(P<0.05, P<0.05)$. These data provide genetic evidence that the Fas/FasL interaction is essential for OxLDL-induced endothelial cell apoptosis.

To elucidate how oxidized lipids activate the Fas death pathway, cultured HAECs or HUVECs were incubated with combinations of neutralizing anti-FasL antibody and agonistic anti-Fas antibody in the presence or absence of OxLDL or LPC. Typically endothelial cells are resistant to Fas-mediated cell death in response to Fas ligand overexpression (18) or ligation of cell surface Fas with agonistic anti-Fas antibodies (Fig. 5). Surprisingly, incubation with OxLDL permitted the agonistic anti-Fas antibody to trigger apoptosis, as detected by FACS analysis after TUNEL staining, when endogenous FasL was blocked by the neutralizing antibody (Fig. $5 \mathrm{~A}$ ). Consistent with these data, decreased mitochondrial function in the MTT assay could be induced by the agonistic anti-Fas antibody in the presence of OxLDL or LPC when endogenous FasL was blocked by the neutralizing antibody (Fig. $5 B$ ). These findings indicate that oxidized lipids kill endothelial cells by increasing the responsiveness of cells to Fas ligation.

\section{Discussion}

Previously, we showed that vascular endothelial cells express both Fas and FasL, and that these cells are normally resistant to Fas-mediated apoptosis (18). Here, we demonstrate that oxidized lipids induce apoptosis in endothelial cells by activating the Fas death pathway. Oxidized lipid-induced endothelial cell apoptosis, identified by changes in cell shape, nuclear condensation, DNA fragmentation, and reduced mitochondrial function, was inhibited by incubation with a neutralizing antibody to FasL. Neutralizing anti-FasL antibodies also inhibited oxidized lipid-induced endothelial cell death in cultured arterial rings, and aortic endothelia prepared from FasL- or Fas-deficient mice were resistant to OxLDL-induced death. Collectively, these data indicate that the Fas/FasL pathway is a key feature of apoptosis induced by acute exposure to oxidized lipid.

Endothelial cell apoptosis induced by moderate levels of copper-oxidized LDL, ferrous-oxidized (minimally modified) LDL, LPC-C16:0, or LPC-C18:0 was blocked by treatment with the neutralizing anti-FasL antibody. At higher levels of oxidized lipids (OxLDL > $400 \mu \mathrm{g}$ protein/ml, LPC-C16:0 $>80$ $\mu \mathrm{M}$, or LPC-C18:0 > $60 \mu \mathrm{M}$ ), cell death was unaffected by inhibition of the Fas pathway (data not shown), indicating that other cytotoxic mechanisms are also triggered by these agents. In this study, cytotoxic effects of these agents were examined in $2 \%$ (cell culture) or $0.5 \%$ (organ culture) FBS. Endothelial cells were more resistant to OxLDL in the presence of higher concentration of serum $(>10 \%)$ or after pretreatment with high serum medium (data not shown). The presence of high 


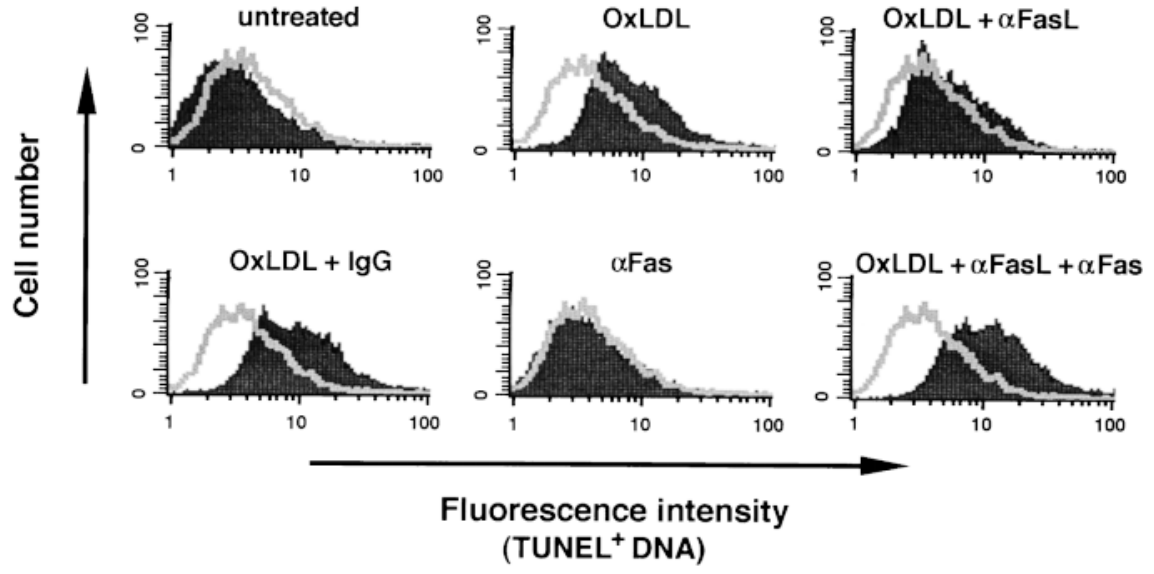

B

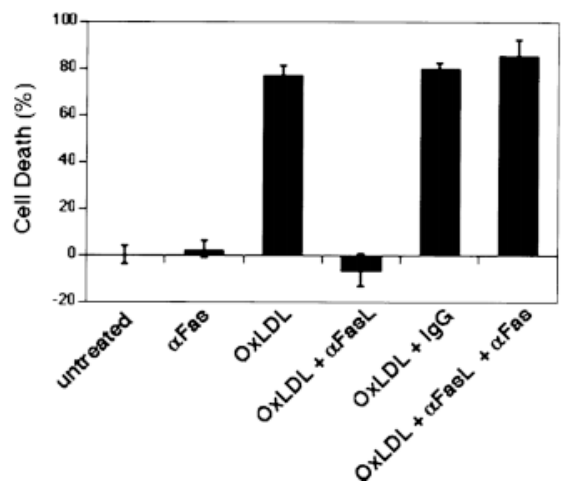

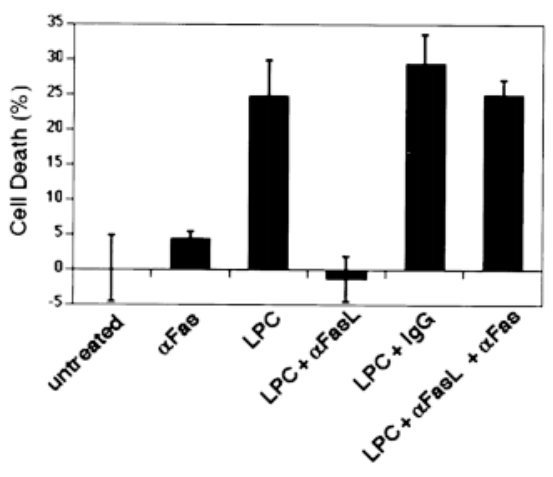

Figure 5. OxLDL and LPC sensitize endothelial cells to Fas-mediated apoptosis. (A) OxLDL induces DNA fragmentation in HUVECs through sensitization to Fasmediated apoptosis. $70 \%$ confluent HUVECs were incubated in the presence or absence of OxLDL (300 $\mu \mathrm{g}$ protein/ml), a neutralizing anti-FasL antibody $(10 \mu \mathrm{g} /$ $\mathrm{ml}, 4 \mathrm{H} 9)$, or an agonistic anti-Fas antibody $(0.5 \mu \mathrm{g} / \mathrm{ml}, \mathrm{CH} 11, \mathrm{MBL})$ for $16 \mathrm{~h}$ in the indicated combinations. Hamster IgG was used as an isotype-matched control for 4 H9. Attached and floating cells were harvested and combined, and incubated with TUNEL solution (Boehringer Mannheim) in the absence (open curve) or in the presence (filled curve) of terminal deoxynucleotidyl transferase. Fluorescence intensity of the TUNEL-positive DNA was analyzed by FACS ${ }^{\mathrm{TM}}$. (B) MTT assays of HAEC sensitivity to Fas-mediated apoptosis induced by OxLDL or LPC. HAECs were cultured in a 96-well plate at $80 \%$ confluency and incubated in the presence or absence of OxLDL $(300$ $\mu \mathrm{g}$ protein/ml) (left), LPC-C16:0 $(55 \mu \mathrm{M})$ (right), a neutralizing anti-FasL antibody $(\alpha \mathrm{FasL}, 10 \mu \mathrm{g} / \mathrm{ml}, 4 \mathrm{H} 9)$, or an agonistic anti-Fas antibody ( $\alpha$ Fas, $0.5 \mu \mathrm{g} / \mathrm{ml}, \mathrm{CH} 11$ ) for $18 \mathrm{~h}$ in combinations as indicated. Cell viability was determined by means of MTT assay (24). density lipoprotein (33) or survival factors (34) in serum may modulate endothelial cell sensitivity to OxLDL-induced cytotoxicity.

Copper-oxidized LDL has been widely used to study the biological activity of OxLDL $(10,11,35,36)$, but a recent study suggests that copper-oxidized LDL may not represent the relevant form of in vivo modified LDL (37), indicating that one must exert caution in extrapolating in vitro findings with copper-oxidized LDL to the in vivo state. However, circulating OxLDL can be detected in blood of patients with hyperlipidemia using antibody raised against copper-oxidized LDL (38), and monoclonal autoantibodies from apolipoprotein E-deficient mice recognize epitopes in copper-oxidized LDL (39). OxLDL and its components have also been detected in atherosclerotic plaque of humans (3), apolipoprotein E3-leiden transgenic mice (40), and Watanabe heritable hyperlipidemic rabbits $(3,4)$. Taken together, these findings demonstrate that OxLDL is present in vivo and suggest that our results provide insights about the pathophysiology of OxLDL toxicity in endothelial cells.

Oxidized lipids influence the Fas/FasL pathway in endothelial cells in at least two ways. First, they increase cell surface expression of FasL with no detectable effect on the level of cell surface Fas expression. Second, they sensitize endothelial cells to death signals from the Fas receptor. This conclusion is indicated by the finding that an agonistic anti-Fas antibody can kill endothelial cells in the presence, but not absence, of oxidized lipids when endogenous FasL is inactivated by a neutralizing antibody. Endothelial cells are normally refractive to apoptosis in response to Fas ligand overexpression (18). Therefore, these data suggest that oxidized lipids do not kill endothelial cells by upregulating FasL alone, but instead, by increasing the responsiveness of endothelial cells to Fas ligation.

There are several mechanisms that may account for the increased sensitization of endothelial cells to Fas-mediated cell death by OxLDL. First, OxLDL may alter the levels of the bcl-2 family of proteins, which function as positive and negative regulators of apoptosis, including Fas-mediated apoptosis in some $(41,42)$ but not all cell types $(43,44)$. Second, OxLDL may activate the Fas pathway through receptor aggregation, as has been reported for ultraviolet radiation-induced apoptosis (45). Third, OxLDL might bring about changes in the intracellular Fas-signaling pathway. Candidate targets include the FADD-binding suppressors of apoptosis that have been reported by several groups (46-48), but the function of these molecules is controversial with some groups proposing that they act as death activators $(49,50)$. Finally, other factors have been reported to modulate Fas-mediated cell death including sentrin (51), GD3 ganglioside (52), and nitric oxide $(53,54)$, which themselves may be modulated by OxLDL.

Recent evidence suggests that cells expressing both FasL and Fas can become dramatically sensitized to the Fas-mediated apoptosis in response to specific stimuli and injuries. There is increasing evidence that alterations in cancer cell sen- 
sitivity to Fas-mediated apoptosis is a key feature controlling tumor progression (15-17), and perturbations in the Fas/FasL cell suicide pathway appear to be important in determining the viability of transformed cells (55-57). Ultraviolet- or $\gamma$-radiation-induced apoptosis is also reported to be mediated by an activation of the Fas/FasL pathway $(45,58)$, and it is well established that $\mathrm{T}$ lymphocyte number is controlled by a delayed sensitization to Fas/FasL-mediated suicide after activation (59). The data presented here suggest that OxLDL enhances the sensitivity of endothelial cells to Fas-mediated cell suicide leading to a disruption of the endothelium. Because the status of endothelial cells is critical for vessel wall homeostasis (20), alterations in endothelial cell sensitivity to Fas-mediated apoptosis may play a role in vascular disease.

At this time it is difficult to assess the overall impact of the endothelial Fas/FasL system in atherogenesis. On one hand, endothelial FasL can function to inhibit leukocyte extravasation by inducing apoptosis in mononuclear cells invading the vessel wall in the absence of normal inflammatory stimuli (18). In this context, FasL may have a protective role, as abnormal leukocyte adhesion to the endothelium and extravasation is an early event in atherogenesis (20). On the other hand, oxidized lipids can increase the sensitivity of endothelial cells to death signals from the Fas receptor. As injuries to endothelium trigger inflammatory processes, sensitization to Fas-mediated apoptosis may contribute to atherosclerosis that results from exaggerated hyperlipidemia. Further studies on Fas, Fas ligand, and the Fas-signaling pathway in endothelial cells may provide a mechanistic rationale for inflammatory cell accumulation that is characteristic of fibroproliferative disorders of the vessel wall.

\section{Acknowledgments}

This work was supported by National Institutes of Health grants AG15052 and HL50692 to K. Walsh.

\section{References}

1. Scandinavian Simvastatin Survival Study Group. 1994. Randomized trial of cholesterol lowering in 4444 patients with coronary heart disease: the Scandinavian Simvastatin Survival Study (4S). Lancet. 344:1383-1389.

2. Steinberg, D. 1997. Low density lipoprotein oxidation and its pathological significance. J. Biol. Chem. 272:20963-20966.

3. Ylä-Herttuala, S., W. Palinski, M.E. Rosenfeld, S. Parthasarathy, T.E. Carew, S.W. Butler, J.L. Witztum, and D. Steinberg. 1989. Evidence for the presence of oxidatively modified LDL in atherosclerotic lesions of rabbit and man. J. Clin. Invest. 84:1086-1095.

4. Haberland, M.E., D. Fong, and L. Cheng. 1988. Malondialdehyde altered protein occurs in atheroma of Watanabe heritable hyperlipidemic rabbits. Science. 241:215-218.

5. Kugiyama, K., S.A. Kerns, J.D. Morrisett, R. Roberts, and P.D. Henry. 1990. Impairment of endothelium-dependent arterial relaxation by lysolecithin in modified low-density lipoproteins. Nature. 344:160-162.

6. Murugesan, G., and P.L. Fox. 1996. Role of lysophosphatidylcholine in the inhibition of endothelial cell motility by oxidized low density lipoprotein. $J$. Clin. Invest. 97:2736-2744.

7. Kume, N., M.I. Cybulsky, and M.A.J. Gimbrone. 1992. Lysophosphatidylcholine, a component of atherogenic lipoprotein, induces mononuclear leukocyte adhesion molecules in cultured human and rabbit arterial endothelial cells. J. Clin. Invest. 90:1138-1144.

8. Escargueil-Blanc, I., O. Meilhac, M.-T. Pieraggi, J.-F. Arnal, R. Salvayre, and A. Negre-Salvayre. 1997. Oxidized LDLs induce massive apoptosis of cultured human endothelial cells through a calcium-dependent pathway. Arterioscler Thromb Vasc Biol. 17:331-339.

9. Dimmeler, S., J. Haendeler, J. Galle, and A.M. Zeiher. 1997. Oxidized low-density lipoprotein induces apoptosis of human endothelial cells by activation of CPP32-like proteases. Circulation. 95:1760-1763.
10. Juckett, M.B., J. Balla, G. Balla, J. Jessurun, H.S. Jacob, and G.M. Vercellotti. 1995. Ferritin protects endothelial cells from oxidized low density lipoprotein in vitro. Am. J. Pathol. 147:782-789.

11. Harada-Shiba, M., M. Kinoshita, H. Kamido, and K. Shimokado. 1998. Oxidized low density lipoprotein induces apoptosis in cultured human umbilical vein endothelial cells by common and unique mechanisms. J. Biol. Chem. 273: 9681-9687.

12. Nagata, S., and P. Golstein. 1995. The Fas death factor. Science. 267: 1449-1456.

13. Griffith, T.S., T. Brunner, S.M. Fletcher, D.R. Green, and T.A. Ferguson. 1995. Fas ligand-induced apoptosis as a mechanism of immune privilege. Science. 270:1189-1192.

14. Bellgrau, D., D. Gold, H. Selawry, J. Moore, A. Franzusoff, and R.C. Duke. 1995. A role of CD95 ligand in preventing graft rejection. Nature. 377:630-632.

15. Hahne, M., D. Rimoldi, M. Schröter, P. Romero, M. Schreier, L.E. French, P. Schneider, T. Bornand, A. Fontana, D. Lienard, J.-C. Cerottini, and J. Tschopp. 1996. Melanoma cell expression of Fas (Apo-1/CD95) ligand: implications for tumor immune escape. Science. 274:1363-1366.

16. Strand, S., W.J. Hofman, H. Hug, M. Müller, G. Otto, D. Strand, S.M. Mariani, W. Stremmel, P.H. Krammer, and P.R. Galle. 1996. Lymphocyte apoptosis induced by CD95 (APO-1/Fas) ligand expressing tumor cells-A mechanism of immune evasion? Nat. Med. 2:1361-1366.

17. Niehans, G.A., T. Brunner, S.P. Frizelle, J.C. Liston, C.T. Salerno, D.J. Knapp, D.R. Green, and R.A. Kratzke. 1997. Human lung carcinomas express Fas ligand. Cancer Res. 57:1007-1012.

18. Sata, M., and K. Walsh. 1998. TNF $\alpha$ regulation of Fas ligand expression on endothelium modulates leukocyte infiltration of the blood vessel wall. Nat. Med. 4:415-420.

19. Sata, M., H. Perlman, D.A. Muruve, M. Silver, M. Ikebe, T.A. Libermann, P. Oettgen, and K. Walsh. 1998. Fas ligand gene transfer to the vessel wall inhibits neointima formation and overrides the adenovirus-mediated $\mathrm{T}$ cell response. Proc. Natl. Acad. Sci. USA. 95:1213-1217.

20. Ross, R. 1993. The pathogenesis of atherosclerosis: a perspective for the 1990s. Nature. 362:801-809.

21. Mach, F., U. Schonbeck, G.K. Sukhova, E. Atkinson, and P. Libby. 1998. Reduction of atherosclerosis in mice by inhibition of CD40 signaling. Nature. 394:200-203.

22. Zhou, X., S. Stemme, and G.K. Hansson. 1996. Evidence for a local immune response in atherosclerosis: $\mathrm{CD}^{+} \mathrm{T}$ cells infiltrate lesions of apolipoprotein-E-deficient mice. Am. J. Pathol. 149:359-366.

23. Liao, F., J.A. Berliner, M. Mehrabian, M. Navab, L. Demer, A.J. Lusis, and A.M. Fogelman. 1991. Minimally modified low density lipoprotein is biologically active in vivo in mice. J. Clin. Invest. 87:2253-2257.

24. Tanaka, M., T. Suda, K. Haze, N. Nakamura, K. Sato, F. Kimura, K. Motoyoshi, M. Mizuki, S. Tagawa, S. Ohga, K. Hatake, A.H. Drummond, and S. Nagata. 1996. Fas ligand in human serum. Nat. Med. 2:317-322.

25. Merrick, A.F., L.D. Shewring, S.A. Cunningham, K. Gustafsson, and W. Fabre. 1997. Organ culture of arteries for experimental studies of vascular endothelium in situ. Transplant Immunol. 5:3-9.

26. Kiener, P.A., P.M. Davis, G.C. Starling, C. Mehlin, S.J. Klebanoff, J.A. Ledbetter, and W.C. Liles. 1997. Differential induction of apoptosis by Fas-Fas ligand interactions in human monocytes and macrophages. J. Exp. Med. 185: 1511-1516.

27. Chow, S.-E., R.-S. Lee, S.H. Shih, and J.-K. Chen. 1998. Oxidized LDL promotes vascular endothelial cell pinocytosis via a prooxidation mechanism. FASEB (Fed. Am. Soc. Exp. Biol.) J. 12:823-830.

28. Van Berkel, T.J.C., Y.B. DeRijke, and J.K. Kruijt. 1991. Different fate in vivo of oxidatively modified low density lipoprotein and acetylated low density lipoprotein in rats. J. Biol. Chem. 266:2282-2289.

29. Sawamura, T., N. Kume, T. Aoyama, H. Moriwaki, H. Hoshikawa, Y. Aibe, T. Tanaka, S. Miwa, Y. Katsura, T. Kita, and T. Masaki. 1997. An endothelial receptor for oxidized low-density lipoprotein. Nature. 386:73-77.

30. Berliner, J.A., M.C. Territo, A. Sevanian, S. Ramin, J.A. Kim, B. Bamshad, M. Esterson, and A.M. Fogelman. 1990. Minimally modified low density lipoprotein stimulates monocyte endothelial interactions. J. Clin. Invest. 85: 1260-1266.

31. Stein, O., and Y. Stein. 1980. Bovine aortic endothelial cells display macrophage-like properties towards acetylated [I-125]-labeled low density lipoprotein. Biochem. Biophys. Acta. 620:631-635.

32. Sugiyama, S., K. Kugiyama, M. Ohgushi, K. Fujimoto, and H. Yasue. 1994. Lysophosphatidylcholine in oxidized low-density lipoprotein increases endothelial susceptibility to polymorphonuclear leukocyte-induced endothelial dysfunction in porcine coronary arteries. Circ. Res. 74:565-575.

33. Suc, I., I. Escargueil-Blanc, M. Troly, R. Salvayre, and A. Negre-Salvayre. 1997. HDL and ApoA prevent cell death of endothelial cells induced by oxidized LDL. Arterioscler. Thromb. Vasc. Biol. 17:2158-2166.

34. Kennedy, S.G., A.J. Wagner, S.D. Conzen, J. Jordan, A. Bellacosa, P.N Tsichlis, and N. Hay. 1997. The PI 3-kinase/Akt signaling pathway delivers an anti-apoptotic signal. Genes Dev. 11:710-713.

35. Galle, J., P. Stunz, P. Schollmeyer, and C. Wanner. 1995. Oxidized LDI and lipoprotein(a) stimulate renin release of juxtaglomerular cells. Kidney Int. $47: 45-52$. 
36. Dimmeler, S., J. Haendeler, J. Galle, and A.M. Zeiher. 1997. Oxidized low-density lipoprotein induces apoptosis of human endothelial cells by activation of CPP32-like proteases. Circulation. 95:1760-1763.

37. Leeuwenburgh, C., J.E. Rasmussen, F.F. Hsu, D.M. Mueller, S. Pennathur, and J.W. Heinecke. 1997. Mass spectrometric quantification of markers for protein oxidation by tyrosyl radical, copper, and hydroxyl radical in low density lipoprotein isolated from human atherosclerotic plaques. J. Biol. Chem. 272:3520-3526.

38. Tamai, O., H. Matsuoka, H. Itabe, Y. Wada, K. Kohno, and T. Imaizumi. 1996. Single LDL apheresis improves endothelium-dependent vasodilatation in hypercholesterolemic humans. Circulation. 95:76-82.

39. Palinski, W., S. Horkko, E. Miller, U.P. Steinbrecher, H.C. Powell, L.K. Curtiss, and J.L. Witztum. 1996. Cloning of monoclonal autoantibodies to epitopes of oxidized lipoproteins from apolipoprotein E-deficient mice. Demonstration of epitopes of oxidized low density lipoprotein in human plasma. $J$. Clin. Invest. 98:800-814.

40. Leppanen, P., J.S. Luoma, H.M. Hofker, L.M. Havekes, and S. YlaHerttuala. 1998. Characterization of atherosclerotic lesions in apo E3-leiden transgenic mice. Atherosclerosis. 136:147-152.

41. Rodriguez, I., K. Matsuura, K. Khatib, J.C. Reed, S. Nagata, and P. Vassalli. 1996. A bcl-2 transgene expressed in hepatocytes protects mice from fulminant liver destruction but not from rapid death induced by anti-Fas antibody injection. J. Exp. Med. 183:1031-1036.

42. Lacronique, V., A. Mignon, M. Fabre, B. Viollet, N. Rouquet, T. Molina, A. Porteu, A. Henrion, D. Bouscary, P. Varlet, V. Joulin, and A. Kahn. 1996. Bcl-2 protects from lethal hepatic apoptosis induced by an anti-Fas antibody in mice. Nat. Med. 2:80-86.

43. Itoh, N., Y. Tsujimoto, and S. Nagata. 1993. Effect of bcl-2 on Fas antigen-mediated cell death. J. Immunol. 151:621-627.

44. Strasser, A., A.W. Harris, D.C.S. Huang, P.H. Krammer, and S. Cory. 1995. Bcl-2 and Fas/APO-1 regulates distinct pathways to lymphocyte apoptosis. EMBO (Eur. Mol. Biol. Organ.) J. 14:6136-6147.

45. Rehemtulla, A., C.A. Hamilton, A.M. Chinnaiyan, and V.M. Dixit. 1997. Ultraviolet radiation-induced apoptosis is mediated by activation of CD95 (Fas/APO-1). J. Biol. Chem. 272:25783-25786.

46. Irmler, M., M. Thome, M. Hahne, P. Schneider, K. Hofmann, V. Steiner, J.-L. Bodmer, M. Schroter, K. Burns, C. Mattmann, D. Rimoldi, L. French, and J. Tschopp. 1997. Inhibition of death receptor signals by cellular FLIP. Nature. 388:190-195.

47. Hu, S., C. Vincenz, J. Ni, R. Gentz, and V.M. Dixit. 1997. I-FLICE, a novel inhibitor of tumor necrosis factor receptor-1 and CD-95-induced apopto- sis. J. Biol. Chem. 272:17255-17257.

48. Srinivasula, S.M., M. Ahmad, S. Otilie, F. Bullrich, S. Banks, T. Fernandes-Alnemri, C.M. Croce, G. Litwack, K.J. Tomaselli, R.C. Armstrong, and E.S. Alnemri. 1997. FLAME-1, a novel FADD-like anti-apoptotic molecules that regulates Fas/TNFR1-induced apoptosis. J. Biol. Chem. 272:1854218545.

49. Shu, H.B., D.R. Halpin, and D.V. Goeddel. 1997. Casper is a FADDand caspase-related inducer of apoptosis. Immunity. 6:751-763.

50. Han, D.K.M., P.M. Chaudhary, M.E. Wright, C. Friedman, B.J. Trask, R.T. Riedel, D.G. Baskin, S.M. Schwartz, and L. Hood. 1997. MRIT, a novel death-effector domain-containing protein, interacts with caspases and BclXL and initiates cell death. Proc. Natl. Acad. Sci. USA. 94:11333-11338.

51. Okura, T., L. Gong, T. Kamitani, T. Wada, I. Okura, C.F. Wei, H.M. Chang, and T.H. Yeh. 1996. Protection against Fas/APO-1 and tumor necrosis factor-mediated cell death by a novel protein, Sentrin. J. Immunol. 157:42774281.

52. Maria, R.D., L. Lenti, F. Malisan, F. d'Agostino, B. Tomassini, A. Zeuner, M.R. Rippo, and R. Testi. 1997. Requirement for GD3 ganglioside in CD95- and ceramide-induced apoptosis. Science. 1997:1652-1655.

53. Melino, G., F. Bernassola, R.A. Knight, M.T. Corasaniti, G. Nistico, and A. Finazzi-Agro. 1997. S-nitrosylation regulates apoptosis. Nature. 388:432-433.

54. Mannick, J.B., X.Q. Miao, and J.S. Stamler. 1997. Nitric oxide inhibits Fas-induced apoptosis. J. Biol. Chem. 272:24125-24128.

55. Muller, M., S. Strand, H. Hug, E.-M. Heinemann, H. Walczak, W.J. Hofmann, W. Stremmel, P.H. Krammer, and P.R. Galle. 1997. Drug-induced apoptosis in hepatoma cells is mediated by the CD95 (APO-1/Fas) receptor/ ligand system and involves activation of wild-type p53. J. Clin. Invest. 99:403413

56. Hueber, A.-O., M. Zornig, D. Lyon, T. Suda, S. Nagata, and G.I. Evan 1997. Requirement for the CD95 receptor-ligand pathway in c-Myc-induced apoptosis. Science. 278:1305-1309.

57. Friesen, C., I. Herr, H. Krammer, and K.-M. Debatin. 1996. Involvement of the CD95 (Apo-1/Fas) receptor/ligand system in drug-induced apoptosis in leukemia cells. Nat. Med. 2:574-577.

58. Reap, E.A., K. Roof, K. Maynor, M. Borrero, J. Booker, and P. Cohen. 1997. Radiation and stress-induced apoptosis: a role for Fas/Fas ligand interaction. Proc. Natl. Acad. Sci. USA. 94:5750-5755.

59. Klas, C., K.-M. Debatin, R.R. Jonker, and P.H. Krammer. 1993. Activation interferes with the APO-1 pathway in mature human T cells. Int. Immunol. 5:625-630. 